\title{
The Use of Calcium and Magnesium Hydroxides in Acid Mine Drainage Treatment

\author{
A. Sulaiman, ${ }^{1}$ A. Othman, ${ }^{1,2 *}$ I. Ibrahim ${ }^{2}$ and M.S. Mohd Rozi ${ }^{2}$
}

${ }^{1}$ Department of Chemistry, Faculty of Science, Universiti Teknologi Malaysia, 81310, Johor Bahru, Johor

${ }^{2}$ Mineral Research Centre, Department of Mineral and Geoscience Malaysia, 31400, Ipoh, Perak

*Corresponding author: anuarpjj@gmail.com

DOI: https://doi.org/10.37134/ejsmt.vol6.1.2.2019

Received: 08 May 2019; Accepted: 08 June 2019; Published: 24 June 2019

\begin{abstract}
Reagent grade of calcium and magnesium hydroxides were used in this study to treat acid mine drainage (AMD) sample. AMD sample was collected from a tin tailing pond that located in Pengkalan Hulu, Perak which as $\mathrm{pH}$ around $2.87 \pm 0.01 . \mathrm{pH}$ values had increased after treated with calcium hydroxide $\left(\mathrm{Ca}(\mathrm{OH})_{2}\right)$ and magnesium hydroxide $\left(\mathrm{Mg}(\mathrm{OH})_{2}\right)$, respectively. The maximum $\mathrm{pH}$ values obtained was $11.35 \pm 0.01$ by using $1.0 \mathrm{~g} \mathrm{of} \mathrm{Ca}(\mathrm{OH})_{2}$ at interval time $5 \mathrm{~min}$. For $\mathrm{Mg}(\mathrm{OH})_{2}$, the highest $\mathrm{pH}$ value can be obtained was $7.22 \pm 0.01$ by using $1.0 \mathrm{~g}$ at interval time $30 \mathrm{~min}$. The concentration of heavy metals such as aluminum, copper, iron, manganese, nickel and zinc were reduced after reaction with both materials. For examples aluminum concentration was reduced from $110.33 \mathrm{mg} / \mathrm{L}$ to $2.80 \mathrm{mg} / \mathrm{L}$ and $0.01 \mathrm{mg} / \mathrm{L}$ by using $1.0 \mathrm{~g}$ of $\mathrm{Ca}(\mathrm{OH})_{2}$ and $\mathrm{Mg}(\mathrm{OH})_{2}$, respectively.
\end{abstract}

Keywords acid mine drainage, calcium hydroxide, magnesium hydroxide, heavy metals

\section{INTRODUCTION}

Calcium and magnesium hydroxides are alkaline materials. Calcium and Magnesium elements are classified in group 2 of periodic table and also known as alkaline earth metals ${ }^{1)}$. Magnesium is second element and calcium is third element in group $2 . \mathrm{Mg}(\mathrm{OH})_{2}$ can be produced via the precipitation of magnesium chloride solution while reacted with slaked lime ${ }^{2)} \cdot \mathrm{Mg}(\mathrm{OH})_{2}$ naturally exists in brucite mineral which is colorless with platy crystals hexagonal shape ${ }^{3)}$. $\mathrm{Mg}(\mathrm{OH})_{2}$ also known as milk of magnesia, it is safely to be handled, non-hazardous and non-toxicity. $\mathrm{Mg}(\mathrm{OH})_{2}$ dissolves in water is slightly around $0.01 \mathrm{~g} / \mathrm{L}^{2)}$.

$\mathrm{Ca}(\mathrm{OH})_{2}$ also known as hydrated lime and can be produced by reacted quicklime $(\mathrm{CaO})$ with a control excess water ${ }^{2)}$. The reaction occurred can be shown in Equation (1). The $\mathrm{pH}$ of $\mathrm{Ca}(\mathrm{OH})_{2}$ in saturated solution at the temperature $25^{\circ} \mathrm{C}$ and pressure 1 atm is 12.4 . The solubility of $\mathrm{Ca}(\mathrm{OH})_{2}$ in water at $0{ }^{\circ} \mathrm{C}, 50$ ${ }^{\circ} \mathrm{C}$ and $100{ }^{\circ} \mathrm{C}$ is $1.85 \mathrm{~g}, 1.28 \mathrm{~g}$ and $0.71 \mathrm{~g}$, respectively ${ }^{2)}$. Hydrated lime also suitable to be used in treating acidic water and then can precipitate certain heavy metals such as manganese, aluminum, zinc, nickel, etc. The heavy metals precipitate based on the $\mathrm{pH}$ controlled. The rate reaction of hydrated lime with sulfuric and hydrochloric acids is depending on the particle size of hydrated lime.

$$
\mathrm{CaO}+\mathrm{H}_{2} \mathrm{O} \rightarrow \mathrm{Ca}(\mathrm{OH})_{2}
$$

AMD is a main problem caused by the mining activities whether in active or abandoned mines especially the area that have sulfide minerals such as pyrite, marcasite, sphalerite, chalcocite, arsenopyrite, etc ${ }^{4)}$. AMD can deteriorate environmental surrounding mining activities especially to aquatic system. AMD occurs when sulfide minerals are oxidized when expose to oxygen and water ${ }^{5}$, and the present of sulfur oxidizing bacteria (SOB) such as Thiobacillus Ferrooxidans that can accelerate the oxidization process ${ }^{6}$. AMD can be defined as $\mathrm{pH} \leq 2$, contains 
high concentration of heavy metals such as aluminum, copper, arsenic, zinc, nickel, etc. AMD also have high concentration of sulfate ${ }^{7)}$. The reaction of AMD occurred as shown in Equation (2) ${ }^{8)}$.

$$
2 \mathrm{FeS}_{2}+7 \mathrm{O}_{2}+2 \mathrm{H}_{2} \mathrm{O} \rightarrow 2 \mathrm{Fe}^{2+}+4 \mathrm{SO}_{4}^{2-}+4 \mathrm{H}^{+}
$$

AMD can be treated by two methods, there are passive and active treatments ${ }^{9}$. Commonly, passive treatment uses biological and certain not reactive chemical materials in treating AMD such as goat dung, cow dung, spent coffee ground (SCG), limestone, dolomite, etc. In this method, reactor or column is used to treat AMD especially from abandoned mine such as in Bukit Besi Mine, Terengganu and Mamut Copper Mine, Sabah. Chemical and biological materials were used together by arrange with different layers. Normally, organic material is placed in first layer and second layer was not reactive chemical in the reactor in a site of abandoned mine. For active treatment, commonly reactive chemicals are used to treat AMD and is carried out in active mine such as in active tin mine in Perak. Apart from calcium and magnesium hydroxides, there are other chemical substances have been used to treat acid mine drainage such as quicklime, carbide lime, magnesium oxide, sodium carbonate, etc. A jar test is used in active treatment that is built in certain location at mine sites before outflow or discharge water enter to the aquatic system. Previous studied shows that calcium and magnesium hydroxides were used in AMD treatment in North Minnesota, $\mathrm{USA}^{10)}$. In this study, AMD sample was from a tin tailing pond and the previous study, AMD samples were collected from coal and generally mention about metal mines and not specified to tin mine. The objective of study is to compare between calcium and magnesium hydroxides which one is suitable to treat AMD. The reactions between hydrated lime and magnesium hydroxide with AMD can be shown in Equations 3 and 4, respectively.

$$
\begin{aligned}
& \mathrm{Ca}(\mathrm{OH})_{2}+\mathrm{H}_{2} \mathrm{SO}_{4} \rightarrow \mathrm{CaSO}_{4}+2 \mathrm{H}_{2} \mathrm{O} \\
& \mathrm{Mg}(\mathrm{OH})_{2}+\mathrm{H}_{2} \mathrm{SO}_{4} \rightarrow \mathrm{MgSO}_{4}+2 \mathrm{H}_{2} \mathrm{O}
\end{aligned}
$$

\section{MATERIALS AND METHODS}

\section{Materials}

AMD sample was collected from a tin tailing pond located at Pengkalan Hulu, Perak. Calcium hydroxide used was reagent grade (Emsure, Germany) and magnesium hydroxide used also was reagent grade (Bendosen, Malaysia).

\section{Methods}

A jar test was carried in the laboratory to study the effectiveness of calcium and magnesium hydroxides in treating AMD. Five different weights of calcium and magnesium hydroxides used in the experiments were 0.2, 0.4 0.6. 0.8 and $1.0 \mathrm{~g}$, respectively. The interval times used for each experiments were 5, 10, 15, 20, 25 and $30 \mathrm{~min}$. Each weight of both materials was added into $1 \mathrm{~L}$ beaker that contained $500 \mathrm{~mL}$ of AMD sample and stirred at $500 \mathrm{rpm}$. Figure 1 shows a jar test before and after reaction between AMD and calcium hydroxide. $\mathrm{pH}$ readings were recorded for each interval times by using Portable $\mathrm{pH}$ meter (A329, Thermo Scientific, Indonesia) and ICP-OES (Optima 5300 DV, Perkin Elmer, USA) was used to detect heavy metals such as aluminum, manganese, nickel, zinc, etc. AMD sample after reaction was filtered by using filter paper Whatman No.1. A few AMD samples after reaction were still cloudy and membrane filter -45 um was used to filter these sample for ICP-OES analysis. 


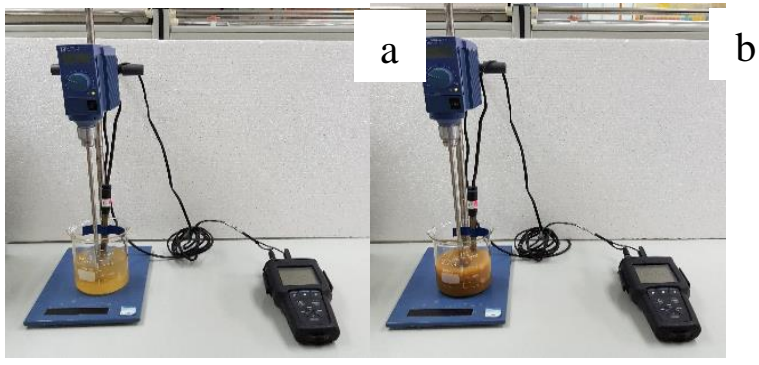

FIG.1 Jar test (a) before and (b) after reaction between AMD and hydrated lime

\section{RESULTS}

\section{pH of calcium and magnesium hydroxides after reaction with amd}

$\mathrm{pH}$ values after reaction with both materials were decreased as shown in Figures 2 and 3, respectively. From Figure 2 showed that after $5 \mathrm{~min}$ reaction, the $\mathrm{pH}$ values had increased from $2.87 \pm 0.01$ to $3.29 \pm 0.01,4.21$ $\pm 0.01,5.39 \pm 0.01,9.01 \pm 0.01$ and $11.34 \pm 0.01$ by using $0.2,0.4,0.6,0.8$ and $1.0 \mathrm{~g}$, respectively. For intervention times $30 \mathrm{~min}, \mathrm{pH}$ values obtained by using $0.2,0.4,0.6,0.8$ and $1.0 \mathrm{~g}$ were $3.18 \pm 0.01,4.26 \pm$ $0.01,5.66 \pm 0.01,9.50 \pm 0.01$ and $10.81 \pm 0.01$ by using $0.2,0.4,0.6,0.8$ and $1.0 \mathrm{~g}$, respectively. The $\mathrm{pH}$ value by using $0.2 \mathrm{~g}$ of calcium hydroxide had decreased from 3.29 to 3.18 cause to the armoring effect that coated surface area of calcium hydroxide particles. Commonly after reaction gypsum and iron hydroxide coated the surface area of calcium hydroxide particles. For calcium hydroxide, the best parameter to treat AMD was $0.6 \mathrm{~g}$ at intervention time 30 min with $\mathrm{pH}$ value $5.66 \pm 0.01$ that complied with Standard B only and nearest to comply with Standard A. The other parameter weights of calcium hydroxide used were not complied with Standards A and B for Environmental Quality Act 1974 (EQA 1974) ${ }^{11)}$. The Standards A and $\mathrm{B}$ for $\mathrm{pH}$ are 6 to 9 and 5.5 to 9 , respectively. Standard A refers to effluent of discharge at the upstream of catchment area and Standard B refers to effluent of discharge at the downstream of catchment area.

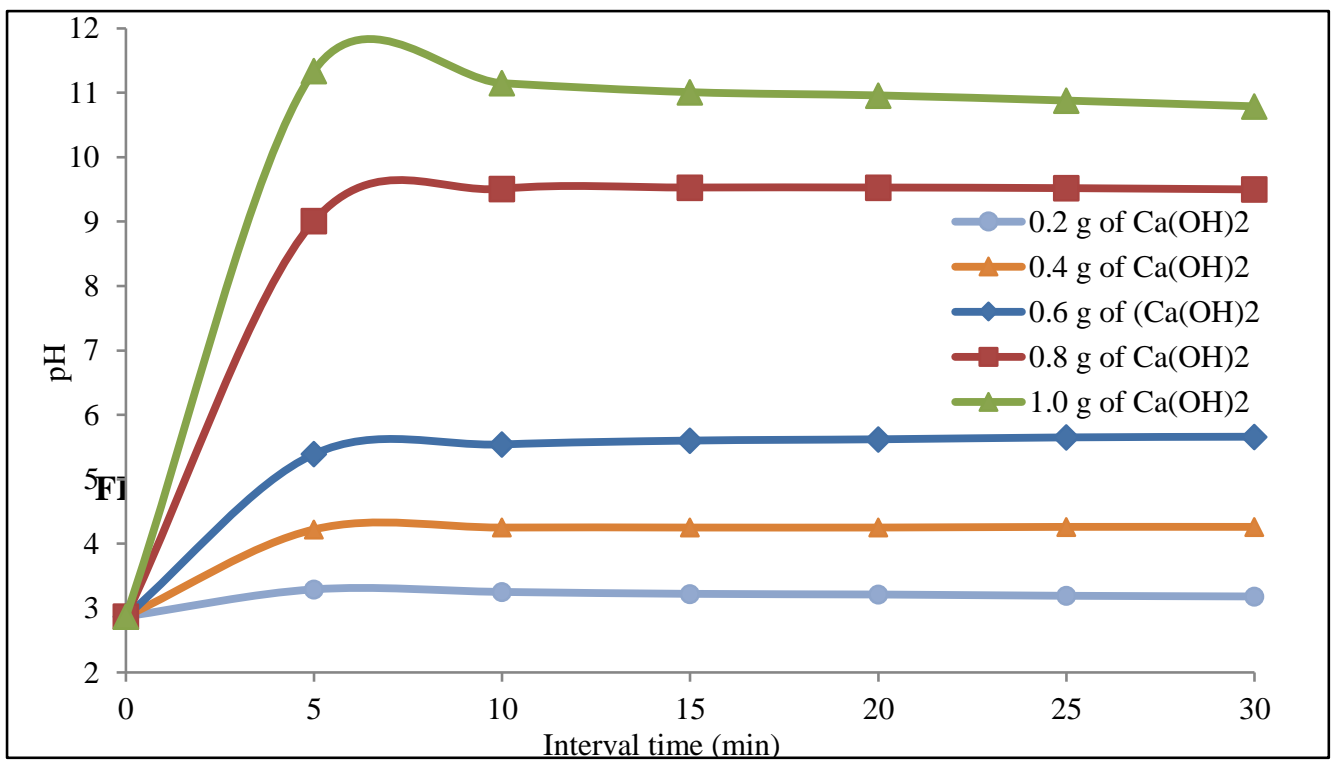


The result from Figure 3 shows that $\mathrm{pH}$ values had increased at intervention time 5 min from $2.87 \pm 0.01$ to $3.49 \pm 0.01,4.60 \pm 0.01,5.09 \pm 0.01,5.63 \pm 0.01$ and $5.97 \pm 0.01$ by using $0.2,0.4,0.6,0.8$ and $1.0 \mathrm{~g}$, respectively. $\mathrm{pH}$ values procured at intervention times 10 were 30 minutes by using $0.2,0.4,0.6,0.8$ and $1.0 \mathrm{~g}$ were $3.53 \pm 0.01,4.72 \pm 0.01,5.62 \pm 0.01,6.25 \pm 0.01$ and $6.50 \pm 0.01 ; 3.57 \pm 0.01,4.91 \pm 0.01,6.40$ $\pm 0.01,6.98 \pm 0.01$ and $7.22 \pm 0.01$, respectively. The results showed that $\mathrm{pH}$ values obtained by using all of magnesium hydroxide parameter weights at intervention time 5 min were not complied with Standards $\mathrm{A}$ and $\mathrm{B}$. pH values obtained at intervention time $10 \mathrm{~min}$ with 0.8 and $1.0 \mathrm{~g}$ of magnesium hydroxide had complied with both standards. $\mathrm{pH}$ values procured at intervention $30 \mathrm{~min}$ by using 0.8 and $1.0 \mathrm{~g}$ of magnesium hydroxide also had complied with Standards A and B. The best parameter chosen to treat AMD was $0.8 \mathrm{~g}$ of magnesium hydroxide at intervention time $10 \mathrm{~min}$. The parameter was selected because it was the minimum weight of magnesium hydroxide to be used to obtained $\mathrm{pH}$ value that complied with both standards.

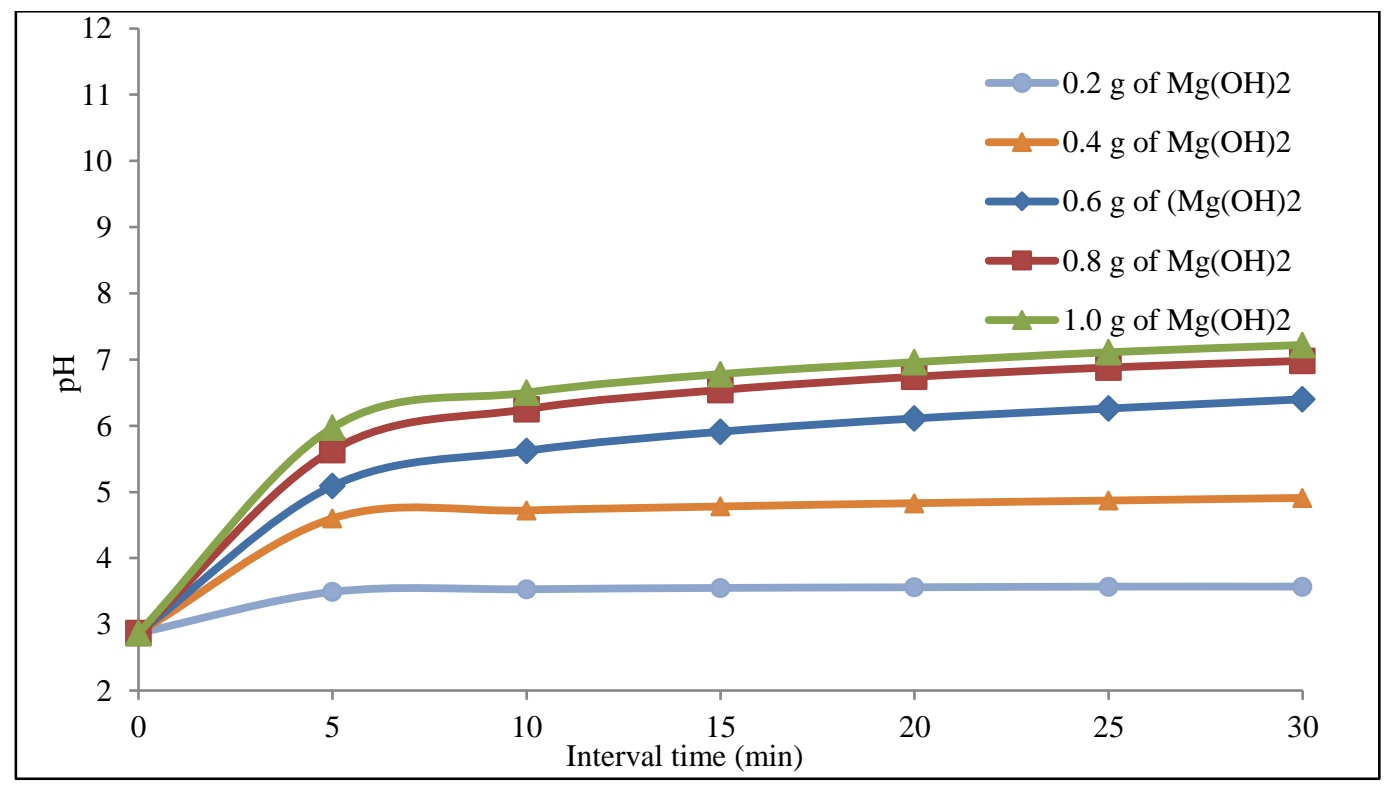

FIG.3 pH of AMD before and after reaction with magnesium hydroxide

\section{HEAVY METALS CONCENTRATION IN AMD BEFORE AND AFTER REACTION}

Figure 4 shows the concentration of arsenic in AMD before and reaction and also Standards A and B Environmental Quality Act 1974. Standards A and B for arsenic are 0.05 and $0.1 \mathrm{mg} / \mathrm{L}$, respectively. The results showed after reaction with $0.2 \mathrm{~g}$ of both materials, arsenic concentration was not complied with both standards. The arsenic concentration obtained after reaction with $0.4 \mathrm{~g}$ of both materials only had complied with Standard A. The concentration of arsenic obtained had complied with both standards by using $0.6,0.8$ and $1.0 \mathrm{~g}$ of both materials. The concentration of arsenic by using $0.6 \mathrm{~g}$ of calcium and magnesium hydroxides were $0.03 \pm 0.00$ and $0.02 \pm 0.00 \mathrm{mg} / \mathrm{L}$, respectively. 


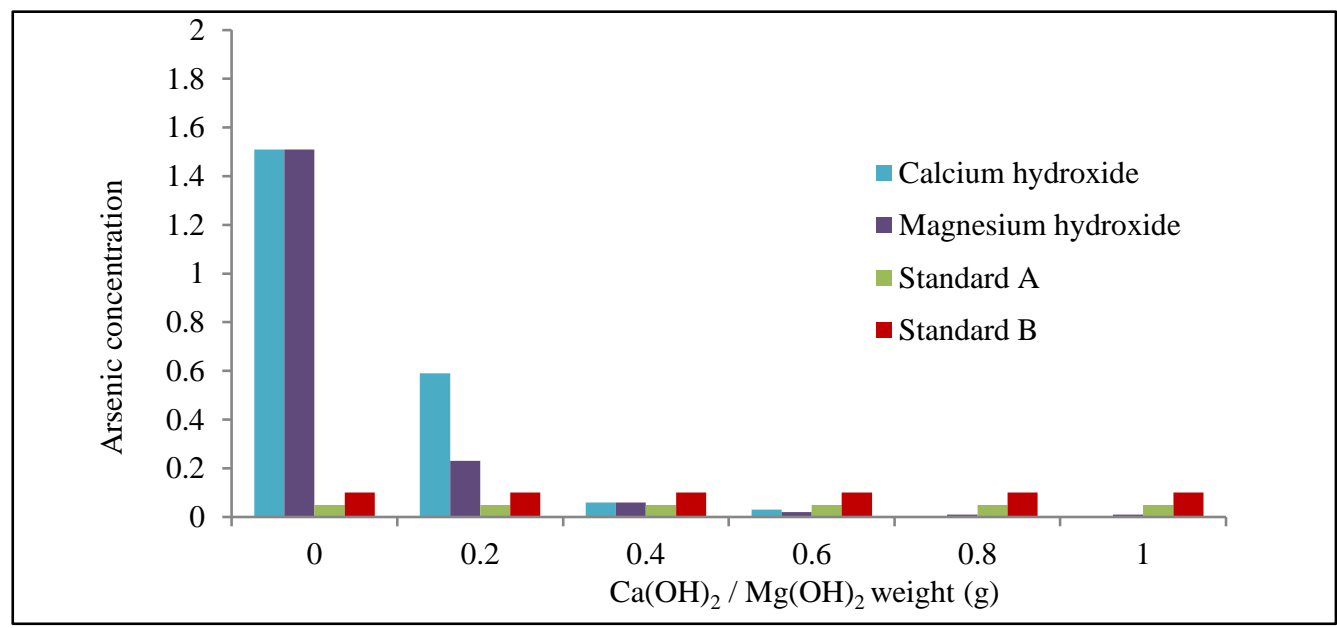

FIG. 4 Arsenic concentration in AMD before and after reaction and Standards A and B arsenic

Figure 5 shows the concentration of zinc in AMD before and reaction and also Standards A and B Environmental Quality Act 1974 for zinc. Standards A and B for zinc are $2.0 \mathrm{mg} / \mathrm{L}$. The results indicated that after reaction only with $0.6 \mathrm{~g}$ of magnesium hydroxide, zinc concentration obtained was $1.82 \pm 0.00$ $\mathrm{mg} / \mathrm{L}$ that complied with Standards A and B of EQA 1974. The concentrations of zinc obtained were complied with both standards by using 0.8 and $1.0 \mathrm{~g}$ of both materials (calcium and magnesium hydroxides).

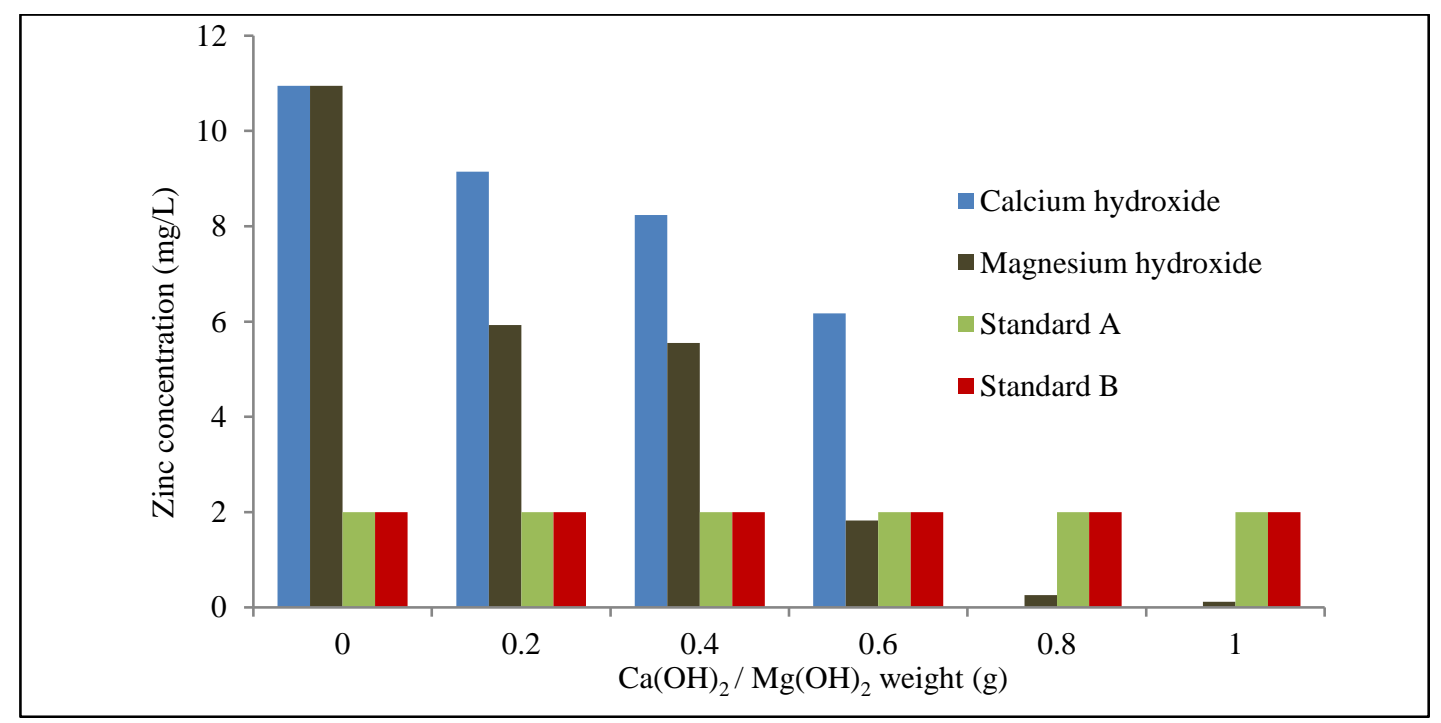

FIG. 5 Zinc concentration in AMD before and after reaction and Standards A and B for zinc

Figure 6 shows the concentration of nickel in AMD before and reaction and also Standards A and B of Environmental Quality Act 1974 for nickel. Standards A and B for nickel are $0.2 \mathrm{mg} / \mathrm{L}$ and $1.0 \mathrm{mg} / \mathrm{L}$, respectively. The results demonstrated that 0.8 and $1.0 \mathrm{~g}$ of calcium hydroxide had capable to reduce nickel concentration that complied with both standards. The nickel concentration was not able to reduce that complied with both standards by using all parameter weights of magnesium hydroxide. 
Figure 7 shows the concentration of manganese in AMD before and reaction and Standards A and B of Environmental Quality Act 1974 for manganese. Standards A and B for manganese are $0.2 \mathrm{mg} / \mathrm{L}$ and 1.0 $\mathrm{mg} / \mathrm{L}$, respectively. The results showed that any doses of magnesium hydroxide weights were not capable

to treat AMD that complied with both standards. Only 0.8 and $1.0 \mathrm{~g}$ of calcium hydroxide had capable to reduce manganese concentration that complied with both standards.

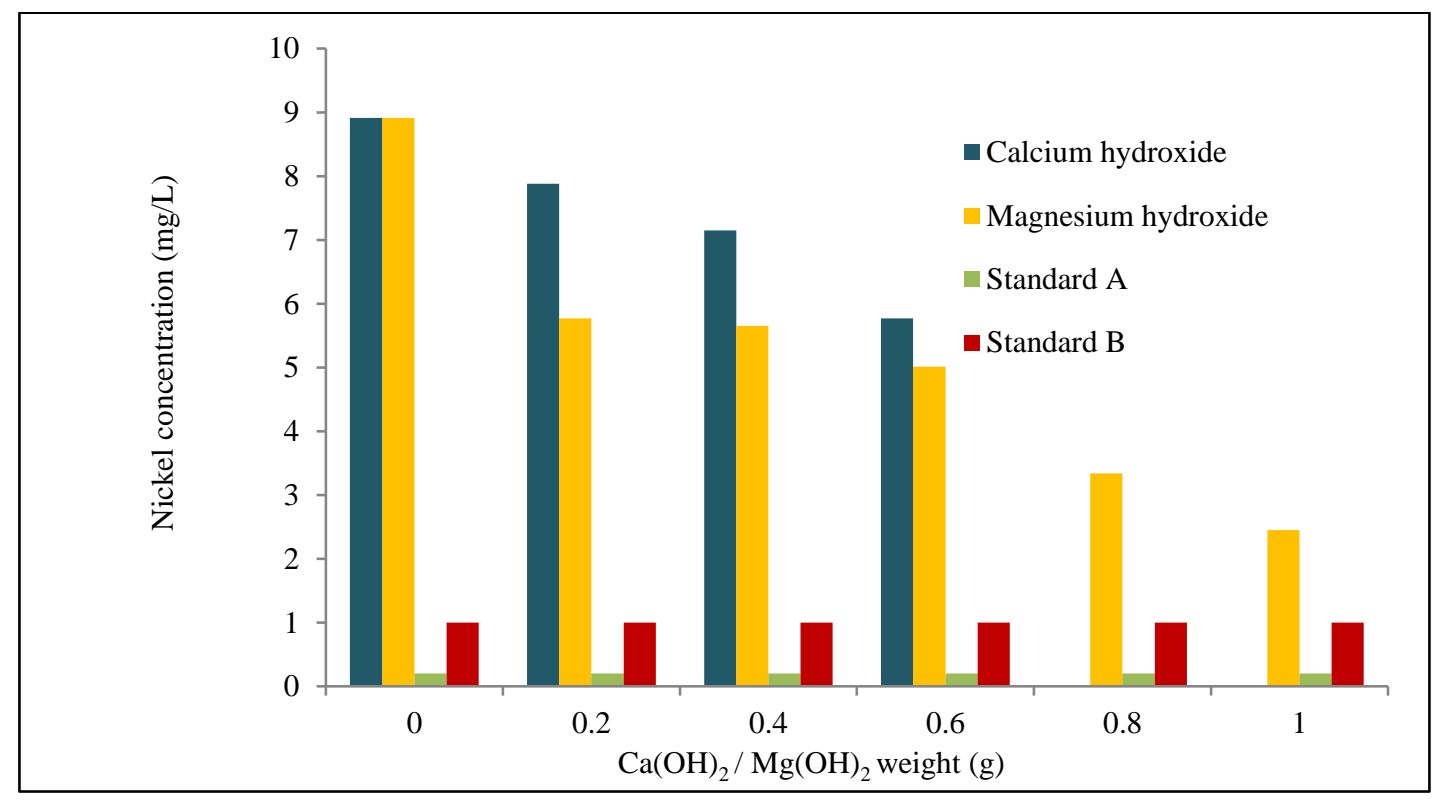

FIG. 6 Nickel concentration in AMD before and after reaction and Standards A and B for nickel

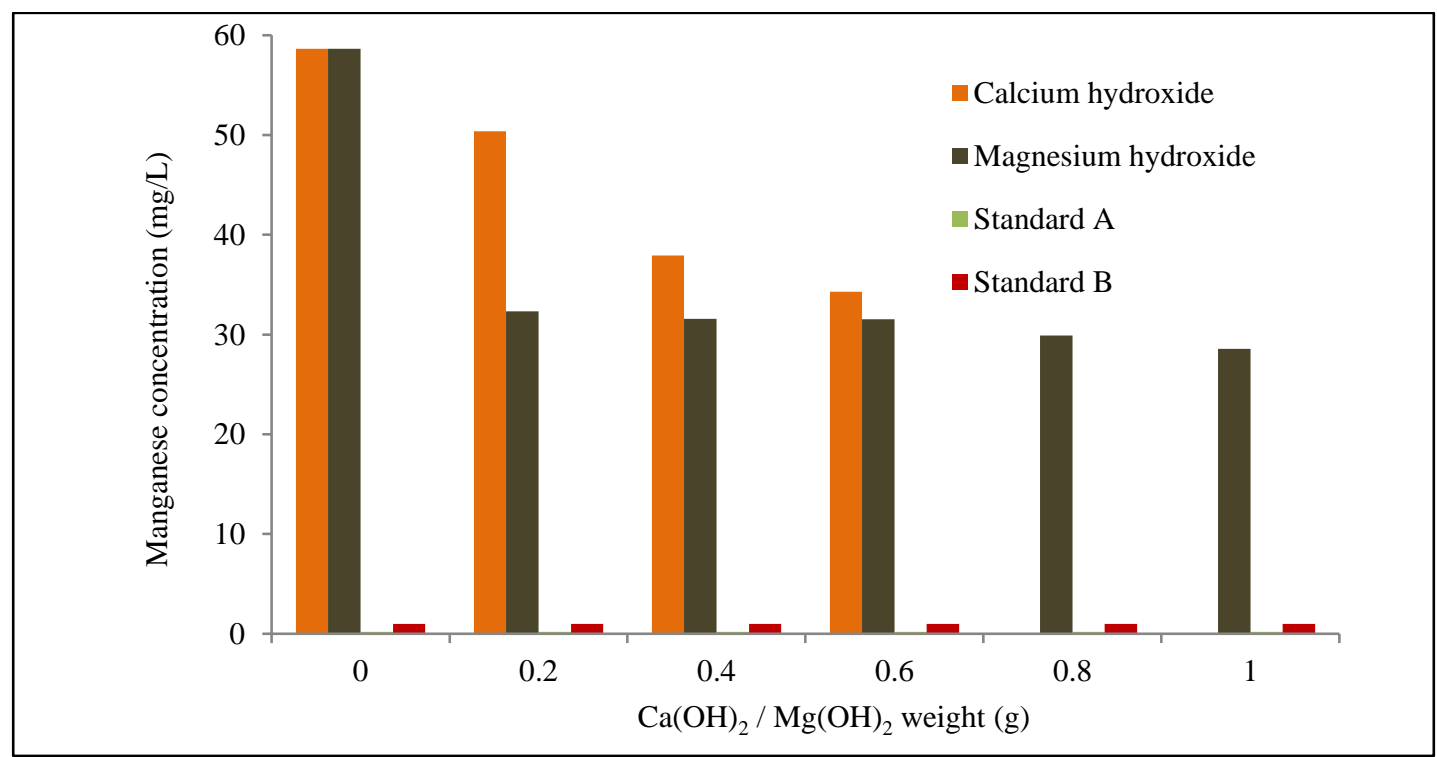

FIG. 7 Nickel concentration in AMD before and after reaction and Standards A and B for manganese 


\section{CONCLUSIONS}

The maximum of $\mathrm{pH}$ value that can be reached to treat $500 \mathrm{~mL}$ of AMD compared to both materials was $11.34 \pm 0.01$ by using $1.0 \mathrm{~g}$ of calcium hydroxide at intervention time $5 \mathrm{~min}$. By using $1.0 \mathrm{~g}$ of magnesium hydroxide, the $\mathrm{pH}$ value can be obtained was $7.22 \pm 0.00$ at intervention time $30 \mathrm{~min}$. The best parameter

chosen was $0.8 \mathrm{~g}$ of magnesium hydroxide that can increase $\mathrm{pH}$ value from $2.87 \pm 0.01$ to $6.25 \pm 0.01$ that complied with Standards A and B. The parameter was chosen because the minimum weight of magnesium hydroxide used to increase the $\mathrm{pH}$ of AMD that complied with both standards. Heavy metals such as arsenic and zinc can be treated that complied with both standards by using $0.8 \mathrm{~g}$ of magnesium hydroxide. The concentrations of arsenic and zinc were decreased from $1.51 \pm 0.09$ to $0.01 \pm 0.00 \mathrm{mg} / \mathrm{L}$ and $10.95 \pm 0.11$ to $0.26 \pm 0.00$, respectively. Calcium hydroxide was not chosen because it can spike $\mathrm{pH}$ value of AMD over than both standards which is for example by using 0.8 and $1.0 \mathrm{~g}$ of calcium hydroxide the $\mathrm{pH}$ values had increased more than 9 that was not complied with Standards A and B.

\section{REFERENCES}

[1] K.H. Buchel, H. H. Moretto and P. Woditsch, Industrial Inorganic Chemistry (Wiley-VCH, German, 1998) p.230.

[2] J.A.H. Oates, Lime and Limestone; Chemistry and Technology, Production and Uses (Wiley-VCH, German, 1998).

[3] H.R. Wenk and A. Bulakh, Minerals theirs Constitution and Origins (Cambridge University Press, UK, 2012) p.422.

[4] G.S. Simate and S. Ndlovu, J. Environ. Chem. Eng. 2, 1785-1803 (2014).

[5] D.B. Johnson, Water Air Soil Pollut.: Focus 3, 47-66 (2003).

[6] A. Akcil and S. Koldas, J. Clean. Product. 14, 1139-1145 (2006)

[7] V. Masindi, V. Akinwekomi, J.P. Maree and K.L. Muedi, J. Environ. Chem. Eng. 5, 3903-3913 (2017)

[8] K. K. Kefeni, T. A.M. Msagati and B. B. Mamba, J. Clean. Product. 151, 475-493 (2017)

[9] S. Heviánková, I. Bestova and M. Kyncl, Minerals Eng. 56,109-111 (2014)

[10]P. Eger, G. Melchert, D. Antonson and J. Wagner, in An Ecological Approach to Mined Land Reclamation: Proceeedings America Society of Mining and Reclamation, Spokane, Washington, 16 May-19 May 1993, edited by B.A. Zamora and R.E. Connolly (American Society for Surface Mining and Reclamation, USA, 1993), pp. 204- 217.

[11] Environmental Quality Act 1974 (Act 127), Regulations, Rules \& Orders. (International Law Book Services, Selangor,2015) p.422. 